\title{
Foreign Corrupt Practices Act: Path to Reduce Environmental Damage
}

\author{
Rosa André Luís Cateli ${ }^{1}$, Messias Ewerton Ricardo ${ }^{2}$ \\ ${ }^{1}$ Faculty of Business, University Center of Integrated Colleges of Ourinhos, Ourinhos-SP, Brazil \\ ${ }^{2}$ Faculty of Law, University of Marília, Marília-SP, Brazil
}

Email address:

andrecateli@gmail.com(R. A. L. Cateli),ewerton_messias@hotmail.com (M. E. Ricardo)

To cite this article:

Rosa André Luís Cateli, Messias Ewerton Ricardo. Foreign Corrupt Practices Act: Path to Reduce Environmental Damage. American Journal of Management Science and Engineering. Vol. 6, No. 2, 2021, pp. 51-55. doi: 10.11648/j.ajmse.20210602.12

Received: December 10, 2020; Accepted: December 22, 2020; Published: June 25, 2021

\begin{abstract}
Carbon neutralization as a way to curb global warming is a matter that occupies a prominent place in the scenario of international law and Brazilian national law. In this context, the way in which the legal system can lead society to contribute to the implementation of carbon neutralization measures proves to be of paramount importance for the legal sciences, which is why this research is justified. Thus, this research aims to study the Foreign Corrupt Practice Acts - FCPA, the North American anti-corruption law, based on the premise that such legislation has foundations capable of, through a process of dynamogenesis, providing practical results for such effectiveness, with the consequent reduction of environmental damage. The investigation was carried out by means of a comparative study, using axiological rationality as the method of approach and, as a procedural method, critical analysis based on the reference system of economic analysis of Law, approached in a relational manner, indicating the efficiency of Law as an inducer of abstaining from harmful conduct to the environment. In the end, it was concluded that the legal application of the fundamentals extracted from the FCPA, having as reference the economic analysis of the law, is able to provide the reduction of environmental damages, through a process of dynamogenesis, capable of resulting in great commitment of the whole society.
\end{abstract}

Keywords: Dinamogenesis, Economics Analysis of Law, Foreign Corrupt Practice Acts, Global Warming, Legal Order

\section{Introduction}

Global warming, which planet Earth has undergone in recent years, has led to climate change, the effects of which have a negative impact on the whole world, so that, if there is no control over the emission of greenhouse gases, the scenario may become even worse.

Current studies show that these climate changes are expected to cause major changes worldwide: sea levels will rise, food production may fall and some species may be extinct [1].

In the last three years, climatologists have changed the definition of what they believe to be the "safe" limit of climate change. For decades, researchers have argued that the rise in global temperature should be kept below $2^{\circ} \mathrm{C}$ until the end of this century to avoid more serious consequences. However, the scientific community now agrees that, in fact, it is necessary to keep temperature increases below $1.5^{\circ} \mathrm{C}$ [1].

The most recent study published by Climate Action
Tracker shows that until the year 2100: (a) if nothing is done, the global temperature will rise between 4.1 and $4.8^{\circ} \mathrm{C}$; (b) following current policies, it will increase between 2.8 and $3.2^{\circ} \mathrm{C}$; and (c) following the current promises of the States, which is less real every day, it will increase between 2.5 and $2.8^{\circ} \mathrm{C}$ [2], still distant from the necessary $1.5^{\circ} \mathrm{C}$ indicated as ideals, reason why The present investigation is justified, as it presents legal solutions to solve this huge problem.

Therefore, the problem addressed in this research was the way in which the legal system can lead society to contribute to the implementation of carbon neutralization measures, capable of curbing global warming, as a result of the intense industrialization process, population increase, urbanization and deforestation experienced in recent decades.

To this end, a study of the Foreign Corrupt Practice Acts FCPA, the North American anti-corruption law, was carried out, which has fundamentals capable of, through a process of dynamogenesis, providing practical results for the reduction of environmental damage. 
The investigation was carried out by means of a comparative study, using axiological rationality as the method of approach and, as a procedural method, critical analysis based on the reference system of economic analysis of Law, approached in a relational manner, indicating the efficiency of Law as an inducer of abstaining from harmful conduct to the environment.

Then, it brings considerations in relation to the proposed reference system and how it is applied, demonstrating the concepts of rationality and the role of Law as an inducer of conduct, in order to provide an adequate foundation for the continuation of the investigation.

The search for the ends of the American law progresses towards the apprehension of the interrelation of these institutes, vital core of the study, whose importance is unique for the verification of the consequences and validity of the application of the foundations of the FCPA for the reduction of environmental damages.

In the end, it was verified that the legal application of the foundations extracted from the FCPA, having as reference the economic analysis of the law, is capable of providing the reduction of environmental damages, through a process of dynamogenesis, capable of resulting in great commitment of the whole society.

\section{2. $\mathrm{CO}_{2}$ Emission and Environmental Damage}

The planet Earth underwent climatic changes that resulted in a phenomenon called global warming, the result of which is the artificial increase in the average temperature of the surface, due to the increase in the emission of gases, mainly resulting from the industrialization process, which has as a landmark the industrial revolution started and continues with greater intensity until today, all added to the population increase, urbanization and deforestation.

The influence of man, mainly through the industrialization process, is causing an increase in the emission of these gases that make up the greenhouse effect, resulting in global warming higher than acceptable for maintaining the climatic balance.

Among the sources that result in an artificial increase in temperature through the greenhouse effect, Charles Armada and Daniela Binotto [3] highlight that $\mathrm{CO}_{2}$ is the gas that has the greatest contribution to global warming, as it represents more than $70 \%$ of GHG emissions and their residence time is at least one hundred years, resulting in impacts on the climate for centuries.

It is also added that methane, despite having a comparatively low concentration (in relation to $\mathrm{CO}_{2}$ ) and its useful life in the atmosphere is low (approximately 12 years), has a significant impact on climate change. Over a 100-year period, it has 25 times the $\mathrm{CO}_{2}$ global warming potential; however, in the short term, this is much stronger: it has a global warming potential 72 times greater than that of $\mathrm{CO}_{2}$ over a 20-year time average. In the case of $\mathrm{N}_{2} \mathrm{O}$ and
Chlorofluorocarbons (CFCs), their concentrations in the atmosphere are lower, but their power to retain heat is 310 to 7,100 times greater than $\mathrm{CO}_{2}$.

Thus, in the last two centuries, the increase in the burning of oil, natural gas and coal, as well as the increase in land use on a large scale due to agriculture and deforestation, have resulted in a significant increase in the emission of one of the gases responsible for the greenhouse effect: Carbon Dioxide $\mathrm{CO}_{2}$.

According to Samuel Vidal [4], this increase in the temperature of the globe may cause drastic climate changes, capable of threatening the quality of life, the socioeconomic standard and even the existence of man, among which he highlights: the increase in the level of the oceans; the emergence and growth of deserts; the imbalance in ecosystems, which will result in new pests and diseases; the increase in hurricanes, typhoons and cyclones; heat waves; and the thawing of permafrost, the permanently frozen soils of the Arctic region. In this sense, Ewerton Ricardo Messias [5] considerations are important, for whom climate change:

[...] have been the cause of catastrophic weather events, such as hurricanes Wilma and Katrina, which occurred in 2005 in the United States, and the three tsunamis between the years 2010 and 2011, respectively, in Chile, Indonesia and Japan.

In Brazil, the effects of global warming are noticeable through the increase in average temperatures, which lead to an increase in the rainfall regime, causing floods and landslides, such as those that occurred in Angra dos Reis, in the State of Rio de Janeiro, and in the State from Santa Catarina, between 2010 and 2012, leaving a large number of dead and homeless (my own translation).

The author continues his reasoning stating that:

It is known that climatic changes, which can be perceived through the alteration of rain regimes, the increase in the intensity of hurricanes, the increase in the level of the oceans, among other factors, are directly related to global warming, and that this has worsened in reason for the absence of public, national and transnational policies, adequate and effective for the reduction of emissions of greenhouse gases, produced by productive processes aimed only at economic development, to the detriment of social and environmental development, where there is the continuous internalization of profits by the rich, followed by the continued socialization of environmental and social risks [5].

Therefore, in order to preserve the environment, it is necessary to promote an efficient carbon neutralization process as soon as possible. In this regard, Jonathan Ramseur [6] clarifies that carbon neutralization has the main objective of reducing, avoiding or sequestering emissions of this gas in the atmosphere, pointing out that compensation can occur through projects, among which he highlights: carbon sequestration, energy energy and energy efficiency.

It appears that carbon neutralization is a solution capable of resolving the problems caused by the greenhouse effect and global warming, which is why it must be treated as a 
fundamental right to development, this in its integral sense, that is, financially viable, socially fair and environmentally responsible [7].

It is worth stressing that the right to development at the Brazilian national level is expressly considered fundamental, since the Brazilian Federal Constitution makes reference to it in its preamble and in art. 3, II, and there is still a simple reference in art. 5th, XXIX.

Thus, the theme can be treated as a process of dynamogenesis, since it refers to the discovery of values by society and social adherence to them, whose realization will take place through the law in its normative production and the effectiveness can be led by education. According to Vladimir Oliveira Silveira and Maria Mendez Rocasolano [8], dynamogenesis:

$[\ldots]$ it refers to the ongoing process in which values are immersed and which can be summarized in the following steps: 1) knowledge-discovery of values by society; 2) subsequent social adherence to values and the immediate consequence; and 3) realization of values through law in its normative and institutional production (my own translation).

Adding to the foundations of the FCPA, which will be explored below, to this process of dynamogenesis, it will be possible to obtain a significant reduction of environmental damages, as will be better explained.

\section{The Basics of Foreign Corrupt Practices Act and Environmental Damage Reduction}

The FCPA is an American legal instrument that presents anti-bribery clauses and on books and accounting records, with the objective of punishing corrupt practices and accounting fraud abroad. It is found in the title 15 - Trade and Negotiation, of the Federal Code of the United States of America, in the device $\$ 78 \mathrm{~m}$ and following.

The purpose of the FCPA is in particular to curb two illicit business practices: bribery and accounting tampering. To this end, economic agents must maintain books and records that accurately reflect transactions, as well as maintain an adequate system of internal accounting controls [9].

The acts of bribery and corruption today are, in fact, the illegal acts of greatest expression in the field of law and with an expressive presence in the international and national context, causing damage to the socioeconomic development of nations victimized by such practices.

Thus, it appears that the FCPA was made feasible to comprehensively cover corrupt conduct, which, before it, was almost impossible to combat, making it a powerful instrument against criminal activities. Sarah Gordon [10] says that:

It was intentionally drafted to cover a wide range of corrupt conduct. There has been a recent increase in FCPA lawsuits and an extension of the scope of the law's antibribery provisions. The Law's broad scope makes it a powerful instrument for taking action against criminal activities that would otherwise be difficult to combat.

The FCPA, in its $\$ 78 \mathrm{dd}-1$, presents, in summary, the commercial practices prohibited to issuers of securities that operate abroad, which demonstrates the extraterritoriality of its reach.

In this way, the FCPA can be applied inside and outside the North American territory. Issuers of securities can be considered local or foreign companies, as well as their directors, employees and shareholders, who issue securities or file reports with the SEC. Jessica Tillipman [11] points out that:

The FCPA is famous for its incredibly wide jurisdiction, to the dismay (and often surprise) of non-American companies that have found themselves regulated by the statutory expansive provisions of the bylaws. The FCPA applies to companies and individuals based on (a) the country in which the improper activity occurred (territorial jurisdiction) or (b) the origin of the party who committed the act (jurisdiction based on nationality). Territorial jurisdiction covers persons or companies that commit an act in the territory of the United States "for the sake of" a corrupt payment or payment offer, using the US post office or other means or instruments of interstate commerce.

Thus, the scope of the law is broad, designed to ensure that companies do not hide behind their agents to avoid liability for acts of corruption and bribery.

This is because responsibility can be imposed not only on those with real knowledge of the illegal practice, but also on those who avoid their knowledge, "which makes clear the need to implement an effective compliance program" [11].

Having as reference the main foundation of the FCPA, which is the accountability of agents who relate to their offenders, it is possible to create a legal scenario capable of resulting in the reduction of environmental damage, through the implementation of a modern legal framework that stipulates penalties for those related to companies that do any damage to the environment, which in practice will involve environmental inspection by the entire community.

The implementation of a legal mechanism in this sense, introduced in the legal system through a process of dynamogenesis, with social adherence to the values pursued through the law in its normative and institutional production, is favorable to the reduction of environmental damage.

\section{Considerations on the Economic Analysis of Law}

The introduction of any legislation is capable of producing far-reaching changes, capable of reaching all economic agents that, in some way, interact in society.

The situation gains special importance from a consequentialist and pragmatic perspective, capable of resulting in social reflexes, taking into account the solid 
bases contextualized by the economic analysis of the law.

In this context of analysis, the legal rules are conceived in an instrumental way, aimed at an efficient solution [12], as will be shown below.

The analysis of economic relations may lead to the possibility of formulating and applying legal norms in a way that makes it possible to make them more efficient from the perspective of obtaining a better economic performance of the nation, reflecting in consequent social welfare [13].

Its usefulness is in finding the rationality of any and all decisions, regardless of whether they are in or out of the market, considering that all human activity "is not instinctive and encompasses this concept and can, therefore, be economically analyzed" [14] (my own translation).

According to Richard Allen Posner [15], the Law must be interpreted and thought from the principles of Economics. Starting with a pragmatic logic, he defends a method of consequentialist interpretation for Law, transforming it into an instrument based on the effects of legal decisions.

In addition, when it comes to the application of the rules by an institution, an essential point to be highlighted is the teaching of Douglas North, who clarifies that "the institutions have the vocation of inducing or restraining conduct based on a valuing judgment" [16].

In this way, when taking Economics as a science that is directly related to the study of human behavior, "its instruments are shown to be powerful for the prospection of the agents' behavior in face of the diverse prescriptions of the legal system" [17] (my own translation).

\subsection{Rational Choice}

To complement the understanding of the economic analysis of law and its application to the insertion of new legislation in the Brazilian national scenario, it is necessary to understand the assumption of rationality in human conduct.

Based on the teachings of Ronald H. Coase [18], rationality consists of the possibility for the individual, whenever faced with a diversity of choices, to evaluate which option offers the greatest benefit, analyzing the losses and opting for the situation that is best for him. In other words, the individual, faced with various possibilities of choice on a daily basis, will choose according to what is best for him, always aiming at his own interests, opting for what provides him the greatest satisfaction.

In this regard, Armando Castelar Pinheiro and Jairo Saddi [19] emphasize that "human beings always seek what they consider to be the best for themselves, preferring more to less satisfaction. Formally, it is said that economic agents act rationally, seeking to maximize their usefulness" (my own translation).

Thus, through economic analysis, the individual makes decisions based on his individual interests, without considering whether "[...] the referred decision is the best to be made for society" [20] (my own translation).

In this context, taking into account the economic analysis, the choice of the human being will depend on the advantages and disadvantages related to compliance and non-compliance with the norm, always prevailing the one that presents the best benefit from the point of view of the individual who practices it.

\subsection{Law as Conduct Inducer}

As demonstrated through rational choice, it is clear that the legal system can influence the conduct of individuals in society. In this sense, Paula A. Forgioni [20] points out that:

[...] legal rules are nothing more than incentives or not incentives for economic agents to act in a certain way. The sanction is simply a price that will be valued by the economic agent according to the cost / benefit logic of their possible behaviors (my own translation).

In view of this context, the idea is complemented by North's teachings, stating that institutions, including legal ones, form the rules of the game, which will serve as a "[...] parameter for the choices made on a daily basis by economic agents" [16].

Pinheiro and Saddi [19] address that Law "[...] influences the conduct of individuals, using sanction and award instruments for this purpose".

Thus, through rationality, taking into account the current legal system, the individual will analyze the individual costs and benefits to make the best decision for himself.

In this scenario, the relationship between law and economics is not merely economic, but has implications for rational choice, resulting in the effects of legislation on the behavior of individuals, so that "this will take into account all externalities arising from their conduct" [21].

It is from this perspective, considering the resulting externalities and the rational choice, that the conclusion of this study will be reached.

\section{Final Considerations}

The climate changes that have occurred in recent years, resulting from global warming due to the increase in the emission of greenhouse gases, have drawn the attention of governments around the world, in view of the already aware possibility of the occurrence of situations, for example: rising sea levels; the emergence and growth of deserts; the imbalance in ecosystems, resulting in new pests and diseases; the increase in hurricanes, typhoons and cyclones; heat waves, and the thawing of permafrost, permanently frozen soils in the Arctic region.

The control of the harmful effects of global warming depends on the adoption of a set of actions capable of assisting in this aim, such as the use of a legal framework capable of presenting a more efficient practical result.

The American Anti-Corruption Act (FCPA), which requires a high degree of compliance, is applicable to all economic agents that have a commercial relationship with the United States. Bearing in mind that the North American market is the largest consumer market in the world. 


\section{Conclusion}

It is concluded, therefore, that the FCPA has extraterritoriality capable of reaching economic agents around the planet, which is possible through a parallel legality attributed by the market. It follows from this that it has as its main aspect the responsibility of any person who relates to agents who violate the rules imposed by it.

It is also concluded that the economic analysis of the law, which takes into account the externalities, the rationality and the transaction costs, attributes to the Law the possibility of being a conduct inducer of the economic agents that participate in the global market. This is because, as demonstrated in this study, market players always seek the best personal position taking into account the observable legislation that falls on them, so that, through rationality, agents tend to abandon relationships that may be susceptible sanctions.

The targeted analysis of the institutes contemplated in the present research, which have progressed towards their integration, leads to the conclusion that the development of the legislation of the Nation States, based on the FCPA principles, having as reference the economic analysis of the law, may be able to provide a reduction in environmental impacts related to global warming, to the extent that agents will have joint and several liability in dealing with companies that contribute to such impacts.

This context, introduced in the legal order of the NationStates, through a process of dynamogenesis, with social adherence to the values pursued by the Law in its normative and institutional production, taking into account the aspects of rationality inherent to the economic analysis, may favor the reach of what is currently proposed by the scientific community with regard to increases in global temperature.

Therefore, it is recommended to carry out future research aimed at analyzing, for example, how it would be possible to expand social adherence to the values pursued by the Law of each Nation-State, in its normative and institutional production, with regard to the reduction increases in climate temperature in line with current scientific recommendations.

\section{References}

[1] STYLIANOU N; GUIBOURG C; DUNFORD D; RODGERS L; BROWN D and RINCON P (2020) Aquecimento global: 7 gráficos que mostram em que ponto estamos. BBC News Brasil, São Paulo, 1: 7.

[2] CLIMATE ACTION TRACKER (2020) CAT Emissions GAP. Web site.

[3] ARMADA C and BINOTTO D (2016) Mudanças climáticas no cenário internacional: antecedentes da COP 21 e perspectivas futuras. Direito e sustentabilidade na era do antropoceno: retrocesso ambiental, balanço e perspectivas 1 : 92.
[4] VIDAL, S (2016) Controlando o aquecimento global: como reduzir em $30 \%$ as emissões de gases estufa até 2030 . E-Book 1: 5-6.

[5] MESSIAS E (2015) Petróleo, gás e mudanças climáticas: ponderação sobre o pagamento por serviços ambientais. Energia e meio ambiente [recurso eletrônico]: contribuições para o necessário diálogo 1: 141-142.

[6] RAMSEUR J (2008) The Role of Offsets in a Greenhouse Gas Emissions Cap-and-Trade Program: Potential Benefits and Concerns. CRS Report for Congress 1: 9-10.

[7] SILVEIRA V and FERNANDES A (2017) O Direito ao Desenvolvimento Integral em face da Política Nacional de Resíduos Sólidos. Revista Jurídica- Unicuritiba, v. 1, n. 46, 1: 54.

[8] SILVEIRA V and ROCASOLANO M (2010) Direitos Humanos: Conceitos, Significados e Funções 1: 191.

[9] USA (2017) Foreign Corrupt Practices Act: an overview. Department of Justice. Web site.

[10] GORDON S (2016) The foreign corrupt practices act: prosecute corruption and end transnational ilegal logging. B. C. Envtl. Aff L. Rev, v. 43, 1: 111-144.

[11] TILLIPMAN J (2014) Hospitality \& the Government Contractor. GW Law School Public Law and Legal Theory Paper. Briefing Papers, n. 14-7, 1: 14.

[12] REPSOLD $M$ and TABAK B (2018) Instrumentos metodológicos da análise econômica do direito e eficiência das políticas públicas executadas pelo terceiro setor. Revista Opinião Jurídica, Fortaleza, ano 16, n. 23, 1: 41.

[13] FERREIRA J and ROSA A (2018) Compliance: contribuição ao desenvolvimento social por meio da Foreign Corrupt Practices Act. Revista de Direito Empresarial - RDEmp, Belo Horizonte, ano 15, n. 2, p. 13-31, maio/ago. 2018, p. 22.

[14] SCHMIDT A (2014) Os primeiros 30 anos do fundo de defesa de direitos difusos sob a luz da análise econômica do direito: "contribuintes", projetos apoiados e novas perspectivas sociais. Argumentum: Revista de Direito, Marília, n. 15, 1: 26.

[15] POSNER R (2010) A economia da justiça. 1: 14.

[16] NORTH D (1994) Economic performance through time. The American Economic Review, Nahville, v. 84, n. 3, 1: 361.

[17] NUSDEO F (2015) Curso de Economia: Introdução ao direito Econômico. 1: 43-44.

[18] COASE R (1988) The firm, the market, and the law. E-Book non paged.

[19] PINHEIRO A and SADDI J (2005) Direito, Economia e Mercados. 1: 89 .

[20] FORGIONI P (2005) Análise econômica do direito (AED): paranoia ou mistificação? Revista de Direito Mercantil Industrial, Econômico e Financeiro, São Paulo, v. 44, n. 139, 1: 248.

[21] FRIEDMAN D (2000) Law's order: what economics has to do with law and why it matters. 1: 08. 